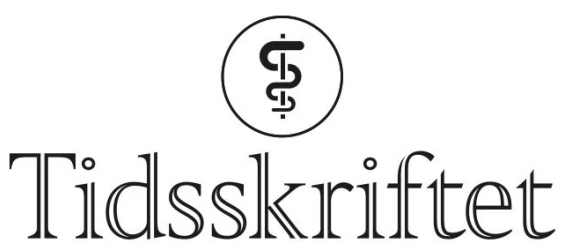

DEN NORSKE LEGEFORENING

\title{
Smittevern blant Oslo-ungdom under covid-19-pandemien
}

ORIGINALARTIKKEL

\author{
TILMANN VON SOEST \\ t.v.soest@psykologi.uio.no \\ Psykologisk institutt \\ Universitetet i Oslo \\ og \\ Velferdsforskningsinstituttet NOVA \\ OsloMet - storbyuniversitetet \\ Han har bidratt med idé, datainnsamling, analyse av data samt utarbeiding, revisjon og godkjenning \\ av manus. \\ Tilmann von Soest er professor og forsker. \\ Forfatteren har fylt ut ICMJE-skjemaet og oppgir ingen interessekonflikter.
}

\section{WILLY PEDERSEN}

Institutt for sosiologi og samfunnsgeografi

Universitetet i Oslo

og

Velferdsforskningsinstituttet NOVA

OsloMet - storbyuniversitetet

Han har bidratt med idé, datainnsamling, tolking av data samt utarbeiding, revisjon og godkjenning av manus.

Willy Pedersen er professor og forsker.

Forfatteren har fylt ut ICMJE-skjemaet og oppgir ingen interessekonflikter.

\section{ANDERS BAKKEN}

Velferdsforskningsinstituttet NOVA

OsloMet - storbyuniversitetet

Han har bidratt med ledelse av datainnsamlingen, analyse av data samt revisjon og godkjenning av manus.

Anders Bakken er forsker og leder for Ungdatasenteret.

Forfatteren har fylt ut ICMJE-skjemaet og oppgir ingen interessekonflikter.

\section{MIRA A. SLETTEN}

Velferdsforskningsinstituttet NOVA

OsloMet-storbyuniversitetet

Hun har bidratt med datainnsamling, tolking av data samt utarbeiding, revisjon og godkjenning av manus.

Mira A. Sletten er forsker og forskningsleder for Seksjon for ungdomsforskning.

Forfatteren har fylt ut ICMJE-skjemaet og oppgir ingen interessekonflikter. 
Effektivt smittevern er avgjørende for å bekjempe covid-19-pandemien. Vi undersøkte om Oslo-ungdom rapporterte å overholde smittevernreglene under pandemien og om oppslutning om reglene var relatert til sosiodemografiske kjennetegn, tillit til myndighetene og aksept av smittevernreglene.

\section{MATERIALE OG METODE}

Elever i ungdomsskolen og videregående skole besvarte et elektronisk spørreskjema ( $\mathrm{N}=12$ 686, 37 \% svar) i en periode med strenge tiltak mot smittespredning. Vi brukte selvrapportering om det å følge smittevernreglene, sosiodemografiske kjennetegn, tillit til myndighetene og til folk flest og aksept av smittevernreglene. Vi benyttet logistisk regresjonsanalyse.

\section{RESULTATER}

Flertallet rapporterte at de i stor grad eller alltid fulgte reglene om håndvask ( $n=9915$, $84 \%)$, ikke håndhilste/klemte ( $n=8730,74 \%)$ og unngikk større grupper $(n=8565,73 \%)$. Færre sa de holdt god avstand til andre $(n=5859,50 \%)$. Tilliten til regjering $(n=8742,80 \%)$ og helsemyndigheter ( $n=9$ 962, 92 \%) var høy. Høyest oppslutning om reglene så man blant jenter, ungdom med innvandrerbakgrunn, de som bor i ytre Oslo øst, de med høy tillit til myndighetene og til folk flest og de som viste aksept for smittevernreglene.

\section{FORTOLKNING}

En stor andel rapporterte at de fulgte smittevernreglene. Ungdom med innvandrerbakgrunn og de bosatt i ytre Oslo øst rapporterte oftere enn andre å følge dem. Tillit samt aksept av reglene var også viktig.

\section{HOVEDFUNN}

Et flertall av Oslo-ungdom i undersøkelsen rapporterte rett etter påsken 2020 at de i stor grad eller alltid fulgte smittevernregler under covid-19-pandemien.

Størst rapportert oppslutning om reglene var det blant jenter, ungdom med innvandrerbakgrunn og blant dem bosatt i ytre Oslo øst.

Svært mange hadde ganske eller veldig stor tillit til regjeringens (8o \%) og helsemyndighetenes (92 \%) håndtering av pandemien, mens færre hadde tillit til at folk flest fulgte smittevernreglene ( $48 \%)$.

Tillit til myndigheter og til folk flest samt aksept av smittevernreglene var relatert til rapportert oppslutning om smittevernreglene.

Strategien for å begrense covid-19-pandemien har vært basert på smittevern og

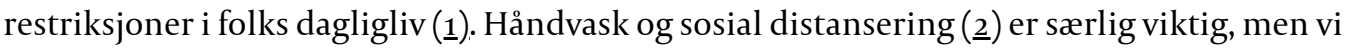
vet lite om hvorvidt smittevernreglene faktisk blir fulgt.

Faglitteraturen er spinkel, men en studie fra England fra mars 2020 viste at $93 \%$ hadde tatt minst én forholdsregel for å beskytte seg mot covid-19 (3). Flest vasket hendene oftere enn ellers (83\%), og rundt halvparten praktiserte sosial distansering. En studie fra Hongkong i januar viste at hele 96 \% rapporterte om hyppigere håndvask, mens 30-70 \% drev med ulike typer sosial distansering. Oppslutningen var lavest blant de yngste, og høyere blant kvinner enn menn (4.). En amerikansk studie som ikke er fagfellevurdert, basert på et bekvemmelighetsutvalg av ungdom fra mars 2020, viste at $30 \%$ hadde ingen kontakt med personer utenfor husholdet, mens 88 \% vasket hendene hyppig (5). En studie fra mars 2020, heller ikke fagfellevurdert, viste at en stor andel norske voksne hadde forandret atferd for å begrense smittespredning og at hyppig håndvask ble praktisert av hele 92 \% (ㅁ). 
$\emptyset$ konomisk svakerestilte grupper og etniske minoriteter ser ut til å rammes hardt av covid19-pandemien. I USA gjelder dette særlig afroamerikanere (7.), og en grunn kan være mangelfull oppslutning om smittevernregler $(\underline{8})$. Data fra Oslo viser at bydeler i velstående Oslo vest var hardt rammet i starten av pandemien, men etter hvert økte smitten mest i ytre Oslo øst, med en befolkning med lav inntekt og utdanning og mange innvandrere. I midten av mai 2020 var Stovner, Alna og Grorud blant bydelene med flest smittede per innbygger, og innvandrere var overrepresentert blant nyinnmeldte covid-19-tilfeller (9,10). Mange faktorer kan tenkes å forklare smitten i ytre øst, som trangboddhet eller sosioøkonomiske faktorer. Men lokale variasjoner i oppslutning om smittevernregler og variasjoner etter bredere sosiodemografiske kjennetegn kan også spille en rolle. Vi vet lite om slike variasjoner.

Generelt er sosioøkonomisk status og tilhørende ulikhet i helserelatert livsstil sterke

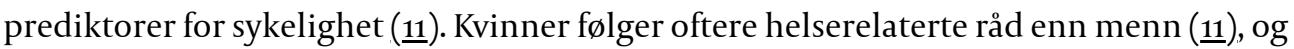
norske data indikerer at kvinner tar flere forholdsregler mot å bli smittet (므). Videre synes de landene som rammes hardest av covid-19-pandemien, å være kjennetegnet av lav tillit mellom mennesker og til myndighetene (므). Det ser ut til at nordmenn har høy tillit til helsemyndighetenes håndtering av covid-19-pandemien (12), men vi vet lite hva det betyr for smitteatferden. Samlet sett er det sannsynlig at man kan finne lavere oppslutning om smittevern blant menn, i grupper med lav utdanning, svake sosioøkonomiske ressurser og lav tillit. Aksept for smittevernreglene kan også være viktig (1).

Vi ville belyse i hvilken grad Oslo-ungdom rapporterer at de overholder smittevernreglene under covid-19-pandemien. Vi unders $ø$ kte om dette varierer etter sosiodemografiske kjennetegn, aksept for smittevernregler og tillit til at covid-19-pandemien håndteres godt av myndigheter og av folk flest.

\section{Materiale og metode}

\section{PROSEDYRE OG DELTAGERE}

Undersøkelsen Oslo-ungdom $i$ koronatiden ble gjennomført 23. april-8. mai 2020. Ved starten hadde skolene vært stengt i seks uker og drev digital hjemmeundervisning. Det var strenge restriksjoner på sosialt samvær. I daglige nyhetssendinger ble reglene for smittevern gjentatt. Alle offentlige skoler i Oslo ble bedt om å delta ved å sette av 30 minutter av hjemmeundervisningen, og $37 \%$ av elevene deltok $(\mathrm{N}=12$ 686). Svarprosenten var høyere på ungdomsskolen $(46 \%, n=8116)$ enn på videregående skole $(27 \%, n=4552 ; 18$ ungdommer oppga ikke klassetrinn). Andel ubesvarte spørsmål (missing) varierte fra $\mathrm{o} \%(\mathrm{n}=13)$ for kjønn til 14\% ( $n=1824)$ for tillit til at statsministeren og regjeringen håndterte covid-19pandemien (spørsmålet ble stilt mot slutten av spørreskjemaet).

Vi sammenlignet sosiodemografiske kjennetegn i vårt utvalg med offentlig statistikk om Oslo-ungdom i samme alder som vi hentet fra Statistisk sentralbyrå for kjønn og innvandrerbakgrunn (13) og fra Oslo kommune for bydel (144). Andel jenter var høyere i undersøkelsen ( $57 \%$ versus $50 \%$ ), det var færre med innvandrerbakgrunn (31\% versus $37 \%$ ) og færre bosatt i ytre og indre Oslo øst (45\% versus $49 \%$ ).

Undersøkelsen ble gjennomført av NOVA ved OsloMet i samarbeid med Utdanningsetaten i Oslo kommune. Elevene fikk skriftlig informasjon om studiens formål og at den var frivillig. Foreldrene ble informert gjennom osloskolens digitale informasjonssystem (Skolemelding). Undersøkelsen var anonym og ikke fremleggelsespliktig for Regional etisk komité for medisinsk og helsefaglig forskning. Utkast av spørreskjemaet ble testet blant elever og vurdert av en referansegruppe med lærere.

VARIABLER

Smittevernreglene. Det finnes ikke validerte instrumenter for å måle smittevernatferd under pandemier (15). Et unntak er et instrument fra en ikke fagfellevurdert studie som verken er tilpasset ungdom eller norske forhold (15). Vi utviklet derfor vårt eget instrument, basert på 
Folkehelseinstituttets smittevernråd (2 $)$. Vi spurte: «I hvor stor grad har du fulgt helsemyndighetenes råd for å redusere smitte?». Vi beskrev fire regler: «Vasket hendene med såpe eller Antibac etter at du har vært ute blant folk», «Unngått å håndhilse på eller klemme på folk», «Holdt godt avstand (1-2 meter) til andre enn de jeg bor sammen med» og «Unngått grupper på mer enn fem personer». Svaralternativer var 1 (ikke i det hele tatt), 2 (i liten grad), 3 (i ganske stor grad), 4 (i stor grad) og 5 (alltid). Svarene ble kombinert til en gjennomsnittsskår, og skårer på 4 eller høyere ble kategorisert som at man i høy grad fulgte reglene.

Sosiodemografiske variabler. Vi spurte om kjønn og klassetrinn. Bosted ble klassifisert i fire områder i Oslo: vestkant (bydelene Vestre Aker, Nordre Aker, Ullern, Frogner, St. Hanshaugen), indre Oslo øst (bydelene Grünerløkka, Gamle Oslo, Sagene), ytre Oslo øst (bydelene Søndre Nordstrand, Bjerke, Stovner, Alna og Grorud) og Østensjø/Nordstrand (bydelene Østensjø og Nordstrand). Foreldres sosioøkonomiske status ble målt på basis av antall foreldre med høyere utdanning, bøker i hjemmet og gjennomsnittsskåren fra Family

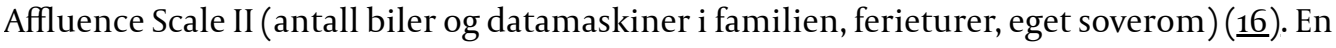
gjennomsnittsskår ble konstruert (트) og brukt til å dele utvalget i tre like store deler: ungdom med lav, middels og høy sosioøkonomisk status. Innvandrerbakgrunn ble definert ut fra om begge foreldrene var født i utlandet. Vi spurte om karakterer i engelsk, norsk og matematikk og delte inn i lave $(1,0-3,9)$, middels $(4,0-4,9)$ og høye $(5,0-6,0)$

gjennomsnittskarakterer.

Tillit til håndtering av covid-19-pandemien. Vi spurte først: «I hvor stor grad stoler du på at de som bestemmer i Norge gjør en god jobb for å takle korona-epidemien?», fulgt av «Statsministeren og Regjeringen» og «Helsemyndighetene». Vi spurte også: «Stoler du på at folk følger de reglene som er blitt innført?» Alle spørsmål hadde «ikke i det hele tatt», «i liten grad», «i ganske stor grad» og «i veldig stor grad» som svarkategorier. Vi dikotomiserte de tre variablene i de som hadde ganske eller veldig stor grad tillit mot alle andre.

Aksept for smittevernreglene. Vi spurte «Hva synes du om alle de reglene som er innført for å hindre at korona-viruset sprer seg (for eksempel stengte skoler, to meters avstand, maks fem i hver gruppe)?», med svaralternativene «Reglene er altfor strenge», «Reglene er akkurat så strenge som de bør være», og «Reglene burde være enda strengere».

\section{Behandling av data og analyser}

Vi brukte enkle logistiske regresjonsanalyser med kategoriseringen basert på det samlete smittevernmålet som utfallsvariabel for å undersøke ujusterte sammenhenger med sosiodemografiske kjennetegn, tillit og aksept av smittevernreglene. Deretter brukte vi multiple logistiske regresjonsanalyser. I en første modell inkluderte vi alle sosiodemografiske kjennetegn samtidig for å undersøke om sammenhengen mellom slike kjennetegn og smittevernsmålet hold seg stabile ved justering for alle andre sosiodemografiske faktorer. I en siste modell inkluderte vi i tillegg tillit og aksept av smittevernreglene som prediktorer for å undersøke om sammenhengene fortsatt forble stabile når alle prediktorvariabler som ble brukt i studien, ble kontrollert for hverandre. I alle regresjonsanalyser inkluderte vi kun respondenter som hadde svart på alle variabler som ble brukt $\mathrm{i}$ analysene $(\mathrm{N}=10382)$.

\section{Resultater}

Figur 1 viser at 9915 (84\%) ungdommer rapporterte at de «i stor grad» eller «alltid» vasket hendene med såpe eller Antibac etter at de hadde vært ute blant folk. Mange rapporterte at de unngikk å håndhilse og klemme $(n=8730,74 \%)$ og å være i større grupper $(n=8565$, $73 \%$ ), mens 5859 ungdommer (50\%) rapporterte at de i stor grad eller alltid holdt 12 meters avstand. Med basis i gjennomsnittsskåren og kategoriseringen vi beskrev over, rapporterte 7304 (62\%) av de 11806 ungdommene som hadde svart på smittevernspørsmålene, at de i høy grad fulgte smittevernreglene. 
Prosentandel

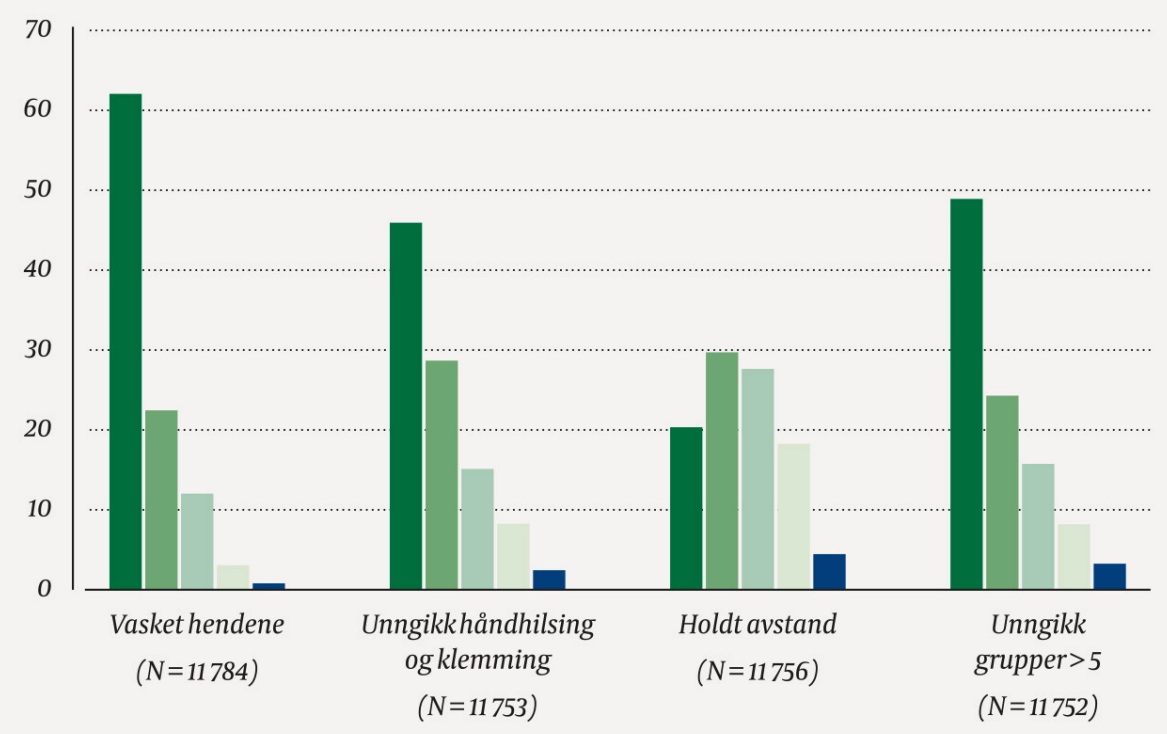

Figur 1 Andel respondenter som rapporterte at de overholdt ulike smittevernregler under covid-19-pandemien. Oslo-ungdom besvarte spørreskjemaet 23.4-8.5.2020.

Figur 2 viser at 9962 ungdommer ( $92 \%$ ) hadde ganske eller veldig stor tillit til helsemyndighetenes håndtering av pandemien. Tilsvarende tall for statsministeren og regjeringen var $\mathrm{n}=8742(8 \mathrm{o} \%)$. Ungdommene hadde lavere tillit til at folk flest overholder smittevernregler $(\mathrm{n}=5255,48 \%) .8408(77 \%)$ mente at reglene var så strenge som de burde være, 986 ( $9 \%$ ) syntes reglene var for strenge og 1547 (14\%) syntes reglene burde vært strengere.

$\square$ Iveldigstorgrad $\square$ Iganskestorgrad Iliten grad $\square$ Ikke idethele tatt

Prosentandel

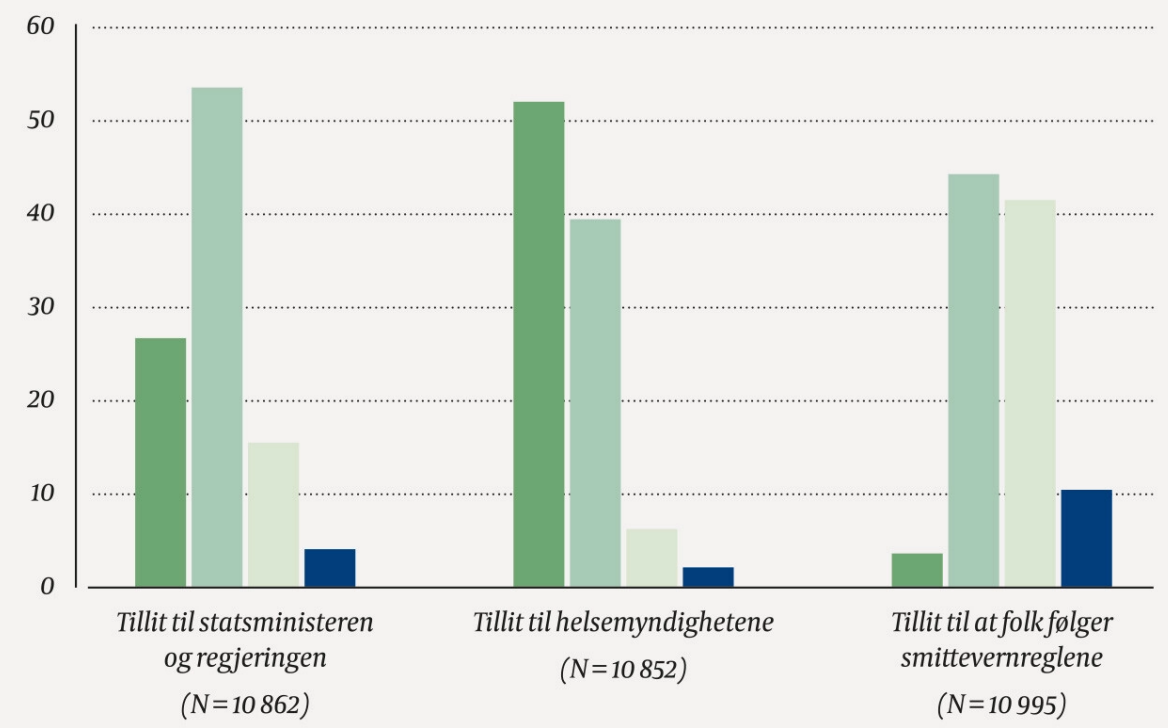

Figur 2 Andel respondenter som rapporterte at de hadde tillit til at myndigheter håndterte covid-19-pandemien og at folk fulgte smittevernreglene. Oslo-ungdom besvarte spørreskjemaet 23.4.-8.5.2020. 
Vi unders $\varnothing$ kte om rapportert oppslutning var relatert til sosiodemografiske faktorer (tabell 1). En større andel jenter (67\%) enn gutter (55\%) fulgte smittevernreglene i stor grad. Ungdom i de to øverste trinnene i videregående skole og ungdom med innvandrerbakgrunn rapporterte oftest at de fulgte reglene. Det samme gjaldt ungdom med bosted i ytre Oslo øst. Rapportert smittevernatferd varierte lite etter foreldrenes sosioøkonomiske status. Men ungdom med høyt karaktergjennomsnitt rapporterte oftere at de fulgte reglene enn de med lavere karaktergjennomsnitt.

\section{Tabell 1}

Andel respondenter som rapporterte at de overholdt i stor grad eller alltid smittevernreglene under covid-19-pandemien, etter sosiodemografiske kjennetegn. Osloungdom besvarte spørreskjemaet 23.4-8.5.2020.

\begin{tabular}{|c|c|}
\hline & $\begin{array}{l}\text { Overholdt smittevernreglene i } \\
\text { stor grad eller alltid, antall (\%) }\end{array}$ \\
\hline \multicolumn{2}{|l|}{ Kjønn (N = 11715$)$} \\
\hline Gutt & $2727(55)$ \\
\hline Jente & $4532(67)$ \\
\hline \multicolumn{2}{|l|}{ Klassetrinn ( $N=11792)$} \\
\hline 8. trinn & $1660(61)$ \\
\hline 9. trinn & $1319(60)$ \\
\hline 10. trinn & $1568(60)$ \\
\hline VG 1 & $1078(60)$ \\
\hline VG 2 & $852(67)$ \\
\hline VG 3 & $817(72)$ \\
\hline \multicolumn{2}{|l|}{ Innvandrerbakgrunn ( $N=11741$ ) } \\
\hline Minst én forelder født i Norge & $4936(60)$ \\
\hline Begge foreldre født i utlandet & $2323(67)$ \\
\hline \multicolumn{2}{|l|}{ Bosted i Oslo ( $N=11664)$} \\
\hline Vestkanten & $2272(60)$ \\
\hline Østensjø og Nordstrand & $1646(60)$ \\
\hline Indre øst & $762(59)$ \\
\hline Ytre øst & $2530(66)$ \\
\hline \multicolumn{2}{|l|}{ Sosioøkonomisk status ( $\mathrm{N}=10382$ ) } \\
\hline Lav & $2379(63)$ \\
\hline Middels & $2283(60)$ \\
\hline Нøу & $2605(63)$ \\
\hline \multicolumn{2}{|c|}{ Gjennomsnittlig skolekarakter ( $N=10581)$} \\
\hline Lav karakter $(1-3,9)$ & $1812(58)$ \\
\hline Middels karakter $(4-4,9)$ & $3065(62)$ \\
\hline
\end{tabular}


Høy tillit var relatert til rapportert oppslutning om reglene, med omtrent like store oddsratioer for alle tre tillitsmål (se tabellene 2 og 3 ). Andelen som rapporterte å følge reglene i høy grad, var lavere for de som syntes at reglene var altfor strenge (40\%), sammenlignet med de som mente de var passe strenge (64\%) og de som syntes de burde vært strengere (71 \%) (tabell 2).

\section{Tabell 2}

Andel respondenter som rapporterte at de overholdt smittevernreglene i stor grad eller alltid under covid-19-pandemien etter tillit til regjeringen, til helsemyndighetene og til andre personer samt aksept av smittevernreglene. Oslo-ungdom besvarte spørreskjemaet mellom 23.4-8.5.2020.

\begin{tabular}{|c|c|}
\hline & $\begin{array}{l}\text { Overholdt smittevernreglene i } \\
\text { stor grad eller alltid, antall (\%) }\end{array}$ \\
\hline \multicolumn{2}{|c|}{ Tillit til statsministeren/regjeringen $(\mathrm{N}=10848)$} \\
\hline Ingen eller liten tillit & $1194(57)$ \\
\hline Ganske eller veldig stor tillit & $5605(64)$ \\
\hline \multicolumn{2}{|l|}{ Tillit til helsemyndighetene $(\mathrm{N}=10843)$} \\
\hline Ingen eller liten tillit & $490(55)$ \\
\hline Ganske eller veldig stor tillit & $6312(63)$ \\
\hline \multicolumn{2}{|c|}{ Tillit til at folk følger smittevernreglene ( $\mathrm{N}=10$ 938) } \\
\hline Ingen eller liten tillit & $3319(58)$ \\
\hline Ganske eller veldig stor tillit & $3529(67)$ \\
\hline \multicolumn{2}{|l|}{ Aksept av smittevernreglene $(\mathrm{N}=10924)$} \\
\hline Er akkurat så strenge som de bør være & $5361(64)$ \\
\hline Er altfor strenge & $395(40)$ \\
\hline Burde vært enda strengere & $1095(71)$ \\
\hline
\end{tabular}

\section{Tabell 3}

Sammenheng mellom ulike forklaringsvariabler og rapportering om at de overholdt smittevernreglene i stor grad eller alltid blant Oslo-ungdom under covid-19-pandemien. $\mathrm{N}$ $=10382$ ungdommer som besvarte alle de aktuelle spørsmålene i spørreskjemaet 23.48.5.2020 ble inkludert i enkle (modell 1) og multiple logistiske regresjonsanalyser med henholdsvis sosiodemografiske faktorer (modell 2) og sosiodemografiske faktorer, tillit og aksept (modell 3 ) som forklaringsvariabler. $\mathrm{OR}=$ oddsratio, $\mathrm{KI}=$ konfidensintervall. 


\begin{tabular}{|c|c|c|c|}
\hline & $\begin{array}{l}\text { Modell } 1 \\
\text { Ujustert OR (95\% } \\
\text { KI) }\end{array}$ & $\begin{array}{l}\text { Modell } 2 \\
\text { Justert OR (95\% } \\
\text { KI) }\end{array}$ & $\begin{array}{l}\text { Modell } 3 \\
\text { Justert OR (95\% } \\
\text { KI) }\end{array}$ \\
\hline \multicolumn{4}{|l|}{ Kjønn (referanse: gutt) } \\
\hline Jente & $1,60(1,47-1,73)$ & $1,53(1,41-1,66)$ & $1,47(1,35-1,60)$ \\
\hline \multicolumn{4}{|l|}{ Klassetrinn (referanse: 8. trinn) } \\
\hline 9. trinn & $1,01(0,90-1,15)$ & $1,00(0,88-1,13)$ & $0,96(0,84-1,09)$ \\
\hline 10. trinn & $0,96(0,86-1,08)$ & $0,94(0,84-1,06)$ & $0,89(0,79-1,01)$ \\
\hline VG 1 & $1,02(0,89-1,16)$ & $1,01(0,89-1,16)$ & $0,99(0,86-1,13)$ \\
\hline VG 2 & $1,34(1,15-1,55)$ & $1,29(1,11-1,50)$ & $1,25(1,07-1,46)$ \\
\hline VG 3 & $1,60(1,36-1,87)$ & $1,56(1,33-1,84)$ & $1,52(1,29-1,79)$ \\
\hline \multicolumn{4}{|l|}{$\begin{array}{l}\text { Innvandrerbakgrunn (referanse: } \\
\text { minst én forelder født i Norge) }\end{array}$} \\
\hline Begge foreldre født i utlandet & $1,34(1,23-1,47)$ & $1,41(1,26-1,57)$ & $1,46(1,31-1,64)$ \\
\hline \multicolumn{4}{|l|}{$\begin{array}{l}\text { Bosted i Oslo (referanse: } \\
\text { Vestkanten) }\end{array}$} \\
\hline Østensjø og Nordstrand & $1,00(0,90-1,12)$ & $1,08(0,97-1,20)$ & $1,10(0,98-1,23)$ \\
\hline Indre øst & $0,99(0,86-1,14)$ & $1,02(0,89-1,19)$ & $1,05(0,91-1,22)$ \\
\hline Ytre øst & $1,30(1,18-1,44)$ & $1,34(1,19-1,50)$ & $1,35(1,20-1,51)$ \\
\hline \multicolumn{4}{|l|}{$\begin{array}{l}\text { Sosioøkonomisk status (referanse: } \\
\text { lav status) }\end{array}$} \\
\hline Middels & $0,93(0,84-1,02)$ & $1,05(0,94-1,17)$ & $1,03(0,92-1,15)$ \\
\hline Нøу & $1,03(0,94-1,14)$ & $1,21(1,08-1,36)$ & $1,20(1,06-1,35)$ \\
\hline \multicolumn{4}{|l|}{$\begin{array}{l}\text { Gjennomsnittlig skolekarakter } \\
\text { (referanse: lav karakter) }\end{array}$} \\
\hline Middels karakter $(4-4,9)$ & $1,20(1,10-1,32)$ & $1,24(1,13-1,37)$ & $1,17(1,06-1,29)$ \\
\hline Høy karakter (5-6) & $1,60(1,42-1,79)$ & $1,61(1,43-1,82)$ & $1,54(1,36-1,74)$ \\
\hline \multicolumn{4}{|l|}{$\begin{array}{l}\text { Tillit til regjering (referanse: lav } \\
\text { tillit }^{1} \text { ) }\end{array}$} \\
\hline Høy tillit ${ }^{2}$ & $1,38(1,25-1,52)$ & & $1,22(1,08-1,38)$ \\
\hline \multicolumn{4}{|l|}{$\begin{array}{l}\text { Tillit til helsemyndigheter } \\
\text { (referanse: lav tillit }{ }^{1} \text { ) }\end{array}$} \\
\hline Høy tillit ${ }^{2}$ & $1,42(1,24-1,63)$ & & $1,11(0,94-1,32)$ \\
\hline \multicolumn{4}{|l|}{ Tillit til folk (referanse: lav tillit ${ }^{1}$ ) } \\
\hline Høy tillit ${ }^{2}$ & $1,48(1,36-1,60)$ & & $1,58(1,45-1,72)$ \\
\hline \multicolumn{4}{|l|}{$\begin{array}{l}\text { Regler (referanse: er akkurat så } \\
\text { strenge som de bør være) }\end{array}$} \\
\hline Er altfor strenge & $0,38(0,33-0,44)$ & & $0,43(0,37-0,49)$ \\
\hline Burde vært enda strengere & $1,41(1,25-1,59)$ & & $1,67(1,47-1,91)$ \\
\hline
\end{tabular}


${ }^{1}$ Inkluderer svarkategoriene «ikke i det hele tatt» og «i liten grad»

${ }^{2}$ Inkluderer svarkategoriene «i ganske stor grad» og «i veldig stor grad»

Resultater fra enkle logistiske regresjonsanalyser med ujusterte oddsratioer er presentert i tabell 3 , modell 1. Tabellen viser at resultatene holdt seg stort sett stabile når vi sammenligner enkle med multiple analyser hvor alle sosiodemografiske kjennetegn ble inkludert samtidig (tabell 3, modell 2), og størrelsen på oddsratioene forandret seg lite. I modell 3 ser vi at graden av tillit til at andre personer følger reglene, fortsatt var relatert til rapportert oppslutning om smittevern, mens betydningen av tillit til regjeringen og helsemyndighetene ble noe redusert. Resultatene viste også at høy sosioøkonomisk status hadde en viss betydning for å overholde smittevernreglene etter kontroll for andre sosioøkonomiske kjennetegn (modellene 2 og 3 ), mens det var ingen slik sammenheng $\mathrm{i}$ ujusterte analyser (modell 1$)$.

\section{Diskusjon}

Vi fant at et klart flertall av Oslo-ungdom som svarte på undersøkelsen, rapporterte at de i stor grad eller alltid fulgte anbefalte smittevernregler under covid-19-pandemien. Det er derimot bare på spørsmålet om håndvask at et flertall av ungdom rapporterte at de alltid fulgte reglene. Ungdom med innvandrerbakgrunn og de bosatt i bydelene i ytre øst rapporterte om høyere oppslutning rundt reglene. Jenter rapporterte å følge reglene oftere enn gutter. Et stort flertall hadde tillit til myndighetenes håndtering av pandemien.

Derimot hadde færre tillit til at folk flest fulgte smittevernreglene. Ni av ti mente at reglene var passe strenge eller at de kunne vært enda strengere. Tillit til myndigheter og folk flest samt aksept av smittevernreglene var relatert til rapportert oppslutning.

Den høye tilliten til helsemyndighetene indikerer at de nok har kommunisert godt med ungdommer under pandemien. Andre norske studier har vist at det samme er tilfellet for voksne (12). Derimot hadde ungdom lavere tillit til at folk flest fulgte smittevernreglene. Det siste kan ha ført til dårligere egenoppslutning rundt reglene.

I tråd med tidligere forskning rapporterte jenter å følge smittevernreglene mer enn gutter $(4, \underline{6})$. Rapportert oppslutning om reglene var lavest blant de yngste ungdommene. Dette kan henge sammen med at medier og myndigheter har framstilt smitte som et mindre problem i unge aldersgrupper. Det er nytt at ungdom med innvandrerbakgrunn og ungdom i ytre øst rapporterer å følge reglene oftere enn andre. Overhyppigheten av smitte i disse områdene kan være relatert til strukturelle faktorer, som trangboddhet, at flere har jobber med høy smitteeksponering og at det kanskje er tettere kontakt på tvers av generasjoner. Det kan også tenkes at ungdom fra ytre øst var mindre varsomme med smittevern i begynnelsen av pandemien da forekomst av smitte var lav i dette området, og at de endret atferd da smittespredningen ble kraftigere.

Det er verdt å merke seg at de få ( $9 \%$ ) som syntes at smittevernreglene var altfor strenge, i mye mindre grad rapporterte å følge reglene. Kausalsammenhengen er ikke kartlagt, og det kan tenkes at de legitimerer brudd på reglene ved å nedtone viktigheten av dem. Likevel indikerer funnene at aksept for restriksjoner er viktig for at smittevernregler følges.

Studiens fortrinn er at den er befolkningsbasert, med et stort utvalg. Den ble gjennomført på et tidspunkt med strenge restriksjoner og da pandemien definerte livet til ungdommene og deres familier. Det er også begrensninger. Vi brukte selvrapportering, og svarene kan farges av at oppslutning om smittevernreglene er sosialt ønskelig (17.). Estimatet for det å følge smittereglene kan derfor være for høyt.

Fordelen med målet er at det ble testet av både ungdom og lærere og at vi spurte ungdom om å rapportere om hvordan de overholdt smittevernreglene i en avgrenset periode på 6-8 uker (fra tidspunktet hvor restriksjonene ble innført til tidspunktet de deltok i studien). 
Dette kan antas å øke reliabiliteten, sammenlignet med spørsmål hvor lengre tidsintervaller er målt retrospektivt (17.). Vi målte grad av oppslutning om reglene og ikke hyppighet av ulike typer atferd. Vi vet derfor ikke hvor ofte ungdom har blitt utsatt for smittefarlige situasjoner. Slik kunnskap ville vært nyttig for å estimere risikoen for at de faktisk kunne bli smittet. Videre kan faktorer vi ikke inkluderte i studien, som bekymring for smitte (므), ha betydning for ungdoms smittevernatferd.

Responsraten er lavere enn ved tilsvarende undersøkelser som Ungdata og Ung i Oslounders $\emptyset$ kelsene ( $\underline{16})$. Mange lærere klarte sannsynligvis ikke å gjennomføre undersøkelsen på kort varsel. Situasjonen var også mindre strukturert enn når elevene svarer i klasserommet. Det er en skjev seleksjon i forhold til sosiodemografiske bakgrunnsvariabler. Dette frafallet kan være knyttet til om man følger smittevernreglene, noe som kan påvirke estimatene.

Funnene kan også avspeile tidspunktet for datainnsamlingen. Den ble gjennomført 6-8 uker etter at strenge restriksjoner ble innført. Nyhetsbildet og hverdagslivet var dominert av pandemien. Senere studier vil kunne rapportere andre funn, fordi myndighetene slakker på tiltakene, fordi det kan oppstå tretthet i befolkningen hvis restriksjonene varer over lengre tid, og fordi fokuset på forhøyet risiko for smitte i Oslo øst kan skifte. Framtidige studier vil vise om funn fra Oslo lar seg generalisere til andre deler av landet.

Vi konkluderer med at et klart flertall av ungdommene i Oslo som deltok i undersøkelsen, rapporterte å ha fulgt smittevernreglene i stor grad. De fleste aksepterte at reglene var nødvendige, og de har hatt høy tillit til myndighetenes håndtering av covid-19-pandemien. Noen vil bli overrasket over at ungdom med innvandrerbakgrunn og de bosatt i ytre Oslo øst i høyere grad enn andre ser ut til å følge reglene. Senere studier bør belyse slike forskjeller og hva de kan skyldes. Mer kunnskap om dette og andre forhold vi belyser, kan bidra til enda mer effektive tiltak for å hindre smittespredning.

Artikkelen er fagfellevurdert.

Arbeidet med studien ble støttet av prosjektmidler fra Norges forskningsråd (prosjektene 288083 og 301010).

\section{LITTERATUR}

1. Regjeringen. Langsiktig strategi og plan for håndteringen av covid-19-pandemien. https://www.regjeringen.no/no/dokumenter/langsiktig-strategi-og-plan-for-handteringen-av-covid19-pandemien-og-justering-av-tiltak/id2701518/ Lest 29.5.2020.

2. Folkehelseinstituttet. Råd og tiltak som gjelder alle.

https://www.fhi.no/nettpub/coronavirus/fakta/avstand-karantene-og-isolering/?term $=\& \mathrm{~h}=1$ Lest 29.5.2020.

3. Atchison C, Bowman L, Eaton JW et al. Public response to UK government recommendations on covid-19: Population survey, 17-18 March 2020. London: Imperial College London, 2020. https://www.imperial.ac.uk/media/imperial-college/medicine/mrc-gida/2O2O-03-2O-COVID19-Report10.pdf Lest 29.5.2020.

4. Kwok KO, Li KK, Chan HHH et al. Community responses during early phase of covid-19 epidemic, Hong Kong. Emerg Infect Dis 2020; 26. doi: 10.3201/eid2607.200500. [PubMed][CrossRef]

5. Oosterhoff B, Palmer CA. Psychological correlates of news monitoring, social distancing, disinfecting, and hoarding behaviors among US adolescents during the covid-19 pandemic. Preprint. https://psyarxiv.com/rpcy4/ Lest 29.5.2020.

6. Zickfeld JH, Schubert TW, Herting AK et al. Correlates of health-protective behavior during the initial days of the COVID-19 outbreak in Norway. Preprint. https://psyarxiv.com/6vgf4/ Lest 29.5.2020.

7. Yancy CW. COVID-19 and African Americans. JAMA 2020; 323: 1891. [PubMed][CrossRef]

8. Hooper MW, Napoles AM, Perez-Stable E. Covid-19 and racial/ethnic disparities. JAMA 2020; 323. doi: 10.1001/jama.2020.8598. [CrossRef]

9. Helseetaten i Oslo. Dagsrapport covid-19, 14. mai. Oslo: Helseetaten, 2020. https://www.oslo.kommune.no/getfile.php/13369018- 
1589530671/Tjenester\%20og\%2otilbud/Koronavirus/Dagsrapporter/Dagsrapport\%2okoronastatistikk\%2 014.5.20.pdf Lest 29.5.2020.

10. Covid-19 ukerapport - uke 19. Oslo: Folkehelseinstituttet, 2020.

https://www.fhi.no/contentassets/8a971e7boa3c4ao6bdbf381ab52e6157/vedlegg/2020.05.12-ukerapportuke-19-covid-19.pdf Lest 29.5.2020.

11. Cockerham W. Social causes of health and disease. Cambridge: Polity Press, 2010.

12. Holte A, Clench-Aas J. Hva er viktigst for den norske velferden fremover, oljefondet eller tillitsfondet? Svaret er enkelt: tillitsfondet. Psykologisk.no.

https://psykologisk.no/2020/o3/mistillitslommene-i-samfunnet-er-dodelige-derfor-er-tillitsfondetenda-viktigere-enn-oljefondet/ Lest 29.5.2020.

13. Statistisk sentralbyrå. SSB Statistikkbanken. https://www.ssb.no/statbank/ Lest 29.5.2020.

14. Oslo kommune. Oslo kommune statistikkbanken. http://statistikkbanken.oslo.kommune.no/ Lest 29.5.2020.

15. Abanoub R, Yi H, Liping Z et al. COVID-19 induced anxiety and protective behaviors during COVID19 outbreak: Scale development and validation. Preprint.

https://www.medrxiv.org/content/10.1101/2020.05.05.20050419v1 Lest 29.5.2020.

16. Bakken A, Frøyland L, Sletten M. Sosiale forskjeller i unges liv. Hva sier Ungdataundersøkelsene? NOVA rapport 2016/3. Oslo: NOVA, 2016. https://bufdir.no/bibliotek/Dokumentside/? docId=BUFoooo 3483 Lest 29.5.2020.

17. Brener ND, Billy JOG, Grady WR. Assessment of factors affecting the validity of self-reported health-risk behavior among adolescents: evidence from the scientific literature. J Adolesc Health 2003; 33: 436-57. [PubMed][CrossRef]

Publisert: 16. juni 2020. Tidsskr Nor Legeforen. DOI: 10.4045/tidsskr.20.0449

Mottatt 18.5.2020, første revisjon innsendt 2.6.2020, godkjent 9.6.2020.

Publisert under åpen tilgang CC BY-ND. Lastet ned fra tidsskriftet.no 26. april 2023. 